\title{
Effect of Plasma Treatment on Growth Parameters and Seed Quality of Bell Pepper (Capsicum annuum L.) under Field Conditions
}

\author{
Cherry Nalwa $^{1 *}$, Ashok K. Thakur ${ }^{1}$ and Amit Vikram²
}

${ }^{1}$ Department of Seed Science and Technology, ${ }^{2}$ Department of Vegetable Science, Dr Y. S. Parmar University of horticulture and Forestry, Solan 173230, Himachal Pradesh, India

*Corresponding author

\begin{tabular}{|l|}
\hline K e y w o r d s \\
Bell pepper, Seed, \\
$\begin{array}{l}\text { Cold plasma, } \\
\text { Osmopriming, } \\
\text { Wettability }\end{array}$ \\
\hline Article Info \\
\hline $\begin{array}{l}\text { Accepted: } \\
\text { 06 August } 2018 \\
\text { Available Online: } \\
\text { 10 September } 2018\end{array}$ \\
\hline
\end{tabular}

\section{Introduction}

Bell pepper (Capsicum annuum L.) commonly known as sweet pepper, capsicum, green pepper or Shimla mirch, belongs to family Solanaceae. It originated in new world tropics and subtropics (Greenleaf, 1986) and was brought to India by the Portugese from Brazil prior to 1885 . It was introduced to Himachal Pradesh by the British in the $19^{\text {th }}$ century. Bell pepper has attained a status of high value crop
This study investigated the effect of cold plasma treatment on growth, fruit and seed parameters of bell pepper (Capsicum annuum L.) cultivar California Wonder. The seeds were exposed to various durations of oxygen cold plasma treatment using glow discharge technique at FCIPT, Institute for Plasma Research, Gandhinagar, Gujarat, India. The seeds were pre-treated with power of $100 \mathrm{~W}$ for treatment durations of $0,3,6,9,12,15$ minutes. The changes in surface morphology of plasma treated seeds were studied by Scanning Electron Microscopy (SEM) and Contact Angle Goniometer. The treatments comprised of primed and non-primed seeds and seven seed plasma treatments. Along with plasma treatment, seeds were also treated with standard osmopriming method for comparison. The plasma treatment alone as well as in combination with osmopriming up to 6 minutes plasma treatment was found superior over all treatments in terms of growth, fruit and seed yield characters. Osmoprimed seeds exposed with 6 minutes plasma were also found to be best treatment for most of the traits recording plant height 30 DAT $(18.97 \mathrm{~cm})$, days to first mature fruit picking (75.33), number of fruits per fruit (17), fruit yield per plant (1.00 $\mathrm{kg}$ ), Number of seeds per fruit (190 g) and thousand seed weight (4.35 g). 
pepper seeds are the major problems that affect the seed quality (McDonald, 1999).

There are different seed enhancement technologies like priming, pelleting, coating, etc that increases the moisture content of seed. Priming is a pre-sowing seed enhancement technique that improves the performance of seed under drought conditions, freshly harvested or aged seeds. Cost effective method for bell pepper is hydropriming which is performed for 24 hours. It is a simple and cost effective strategy for improving germination and emergence of bell pepper (Uche et al., 2016). On the other hand, coating is a practice of covering seeds with external materials to improve handling, protection, germination enhancement and plant establishment. Therefore, a dry seed treatment like plasma treatment is employed which increases the seed coat permeability without increasing the moisture content of seed. Plasma seed treatment method is a physicochemical method which has the potential to improve germination, increase the yield and kill fungal spores which is present on the seed coat (Zhou et al., 2012). Plasma treatment has been successfully applied in agriculture for seed quality improvement, seed enhancement and pathogenic micro-organisms inactivation (Filatova et al., 2013). Crop yields are improved by treating the seeds in a low temperature plasma discharge generated between spaced electrodes connected to a source of high frequency electrical power (Krapivina et al., 1994). Cold plasma treatment is a cost effective method that has been effectively used in seed technology because it is fast economic and pollution free method to improve the seed performance, it decontaminates the pathogens from seeds, no loss of seed quality and a quick treatment with no side effects. Hence, effect of plasma treatment on germination and vigour of bell pepper seeds was studied. However, reports about the effects of cold plasma on bell pepper are limited. The aim of the experiment was (1) to study the effect of cold plasma treatment on growth parameters of bell pepper seeds and (2) to explore the mechanisms of the effects of plasma on fruit and seed quality of bell pepper.

\section{Materials and Methods}

Seeds of bell pepper (Capsicum annuum L.) cultivar California Wonder were obtained from Dr YS Parmar University of Horticulture and Forestry, Solan, HP, India. Seeds were exposed to cold plasma treatment under the following conditions. Glow Discharge plasma of oxygen gas was used at a base pressure of $0.05 \mathrm{~m}$ bar, operating pressure of $0.2 \mathrm{~m}$ bar, voltage of $500 \mathrm{~V}$, current of $0.2 \mathrm{~A}$ and power of $100 \mathrm{~W}$ for treatment durations of $0,3,6,9$, 12 and 15 minutes. Along, with the plasma treatment seeds were also treated with osmopriming for comparison. In osmopriming the seeds are soaked in osmoticum i.e. PEG for about 72 hours at $15^{\circ} \mathrm{C}$ and $90 \%$ relative humidity and after that wash it with tap water 3-4 times. After exposure to plasma the seeds were imaged by high resolution Scanning Electron Microscopy and Contact Angle Goniometer. Seed Surface Topography of plasma treated and untreated seeds were studied by Scanning Electron Microscopy (SEM) at $50 \mathrm{X}$ and $100 \mathrm{~K} \mathrm{X}$ magnifications. And Seed Surface Morphology was studied by Contact Angle Goniometer. Water contact angle quantifies the wettability of a solid surface by a liquid. Control seeds were not exposed to any treatment. Not only the chemical structure but also the roughness of the surface is affected by the plasma treatment, which can change the wettability of the surface (Dubinov et al., 2000).

\section{Statistical analysis}

The experiment was carried out at the Department of Seed Science and Technology, 
Dr Y. S. Parmar University of Horticulture and Forestry, Nauni, Solan from March 2014 to September 2015. Seeds were germinated in petriplates at $22-27^{\circ} \mathrm{C}$. The experiment was planned as a completely randomized design with four replications.

\section{Results and Discussion}

\section{Plant height at 30 days after transplanting (30 DAT)}

Higher plant height at 30 days after transplanting $(15.73 \mathrm{~cm})$ was recorded with osmopriming treatment as compared to nonpriming treatment $(14.85 \mathrm{~cm})$. The plant height at 30 days after transplanting differed significantly due to plasma treatment. Seeds exposed to plasma for 6 minutes recorded highest plant height $(18.05 \mathrm{~cm})$.

The seed kept under vacuum and not exposed to plasma showed significantly low plant height $(13.17 \mathrm{~cm})$ compared to plasma treated seeds. The lowest plant height $(12.79 \mathrm{~cm})$ was recorded in untreated control.

The increased plant height at 30 DAT may be due to early emergence and also rapid cell division in meristematic region, number of cells and increase in cell elongation due to multiplication of various parts of the plant tissue, auxin metabolism, cell wall plasticity and permeability of cell membrane, increasing photosynthates, cell enlargement and rapid cell elongation (Sadavarthe and Gupta, 1963). The results are in conformity with the findings of Zhou et al., (2011) (Table 1).

He reported increase in plant height in tomato seedlings and the possible reason may be the active oxygen particles that can penetrate into the seed, accelerate to decompose the inner nutriment of the seeds, reduce relative penetrability and improve the activities of the root of the tomato seedling.

\section{Days to first mature fruit picking}

It revealed significant variations for the character under study. The early fruit picking (78.81 days) were observed in the osmopriming treatment, whereas, the nonpriming treatment gave the late fruit picking (80.00 days). Days to first mature fruit picking differed significantly due to plasma treatment. Early fruit picking (75.17 days) was recorded in seed exposed to plasma for 6 minutes, whereas delayed first picking (82.00 days) was observed in vacuum seed where no plasma treatment were given. However, the untreated control seed resulted in delayed fruit picking (83.17 days). Days to first fruit picking is an indicator of maturity period in bell pepper. Early maturity is a desirable trait which fetches good yield and returns to the growers. Days to first mature fruit picking differed significantly between osmoprimed and non-primed seed. The early maturity of the crop raised from primed seed may be due to the fact that the plants of primed seeds took fewer days to emerge and flower and ultimately matured earlier than that of nonprimed seed. These results were in agreement with the findings of Barlow and Haigh (1987) who reported earlier ripening in tomato plants raised from primed seed.

\section{Number of fruits per plant}

Number of fruits per plant differed significantly among priming and plasma treated seeds. The Maximum number of fruits per plant (14.53) was observed in osmoprimed seeds whereas; the minimum number of fruits per plant (13.95) was recorded in non-primed seeds. Number of fruits per plant differed significantly due to different exposure of plasma treatments. Seeds exposed to plasma for 6 minutes recorded maximum number of fruits per plant (16.83). The seed kept under vacuum and not exposed to plasma recorded minimum number of fruits per plant (12.67) 
compared to plasma treated seeds. Whereas, the minimum fruits per plant (11.33) was observed in control seed where no vacuum and no plasma treatment were given. Number of fruits per plant is one of the most important characters contributing directly to yields. The crop raised from priming treatment was significant for increase in number of fruits per plant. Shah et al., (2011) was also of the view that priming of okra seeds results in increased number of pods per plant. Increase in number of fruits per plant with osmopriming may be due to early appearance of flowers and more plant height. Plasma treatment had significantly influenced the number of fruits per plant. The increase in number of fruits per plant with seed plasma may be due to early field emergence and longer harvest duration (Sera et al., 2008). Interaction effects between priming treatments and plasma treatments were found to be non-significant for number of fruits per plant.

\section{Fruit yield per plant (kilogram)}

Analysis of variance revealed significant differences for the effect of priming and plasma treatment on fruit yield per plant which is depicted in the Table 2. Significantly higher fruit yield per plant $(0.82 \mathrm{~kg})$ was recorded with osmopriming treatment as compared to non-priming treatment $(0.78 \mathrm{~kg})$. A significant improvement in fruit yield per plant was observed due to different exposure of plasma over control. Seed exposed to plasma for 6 minutes recorded maximum fruit yield per plant $(0.99 \mathrm{~kg})$. The seed kept under vacuum and not exposed to plasma recorded minimum fruit yield per plant $(0.69 \mathrm{~kg})$ compared to plasma treated seeds. The minimum fruit yield per plant $(0.60 \mathrm{~kg})$ was observed in untreated seed i.e. control. Fruit yield per plant differed significantly between osmoprimed and non-primed seeds. The highest fruit yield per plant $0.82 \mathrm{~kg}$ was recorded in osmoprimed seeds while lowest was observed $0.78 \mathrm{~kg}$ ) in non-primed seeds. Increased yield is one of the main objectives of the seed priming. The increase in yield may be due to early emergence, earliness in flowering, more number of fruits per plant and increase in fruit weight. The results are in conformity with Odell et al., (1992), Dabrowska et al., (2000), Harris et al., (2001) and Rashid et al., (2002). They reported increase in yield due to seed priming in tomato, hot pepper, maize and wheat respectively. Plasma treatment had significantly influenced fruit yield per plant.

Table.1 Effect of plasma treatment, seed priming and their interactions on plant height at 30 DAT and days to first mature fruit picking in bell pepper

\begin{tabular}{|c|c|c|c|c|c|c|c|}
\hline $\begin{array}{c}\text { Plasma treatment } \\
\text { durations }\end{array}$ & \multicolumn{3}{|c|}{ Plant height at 30 DAT $(\mathbf{c m})$} & \multicolumn{3}{c|}{ Days to first mature fruit picking } \\
\cline { 2 - 8 } & Osmoprimed & $\begin{array}{c}\text { Non- } \\
\text { primed }\end{array}$ & $\begin{array}{c}\text { Mean } \\
\text { (Plasma) }\end{array}$ & Osmoprimed & $\begin{array}{c}\text { Non- } \\
\text { primed }\end{array}$ & $\begin{array}{c}\text { Mean } \\
\text { (Plasma) }\end{array}$ \\
\hline Vacuum & 13.28 & 13.07 & $\mathbf{1 3 . 1 7}$ & 81.33 & 82.67 & $\mathbf{8 2 . 0 0}$ \\
\hline 3minutes & 17.41 & 16.61 & $\mathbf{1 7 . 0 1}$ & 76.33 & 78.33 & $\mathbf{7 7 . 3 3}$ \\
\hline 6 minutes & 18.97 & 17.14 & $\mathbf{1 8 . 0 5}$ & 75.33 & 75.00 & $\mathbf{7 5 . 1 7}$ \\
\hline 9 minutes & 16.72 & 15.94 & $\mathbf{1 6 . 3 3}$ & 77.33 & 78.67 & $\mathbf{7 8 . 0 0}$ \\
\hline $\mathbf{1 2}$ minutes & 15.62 & 14.54 & $\mathbf{1 5 . 0 8}$ & 78.67 & 80.00 & $\mathbf{7 9 . 3 3}$ \\
\hline $\mathbf{1 5}$ minutes & 14.84 & 14.32 & $\mathbf{1 4 . 5 8}$ & 80.33 & 81.33 & $\mathbf{8 0 . 8 3}$ \\
\hline Control & 13.23 & 12.35 & $\mathbf{1 2 . 7 9}$ & 82.33 & 84.00 & $\mathbf{8 3 . 1 7}$ \\
\hline Mean (Priming) & $\mathbf{1 5 . 7 3}$ & $\mathbf{1 4 . 8 5}$ & & $\mathbf{7 8 . 8 1}$ & $\mathbf{8 0 . 0 0}$ & \\
\hline
\end{tabular}


Table.2 Effect of plasma treatment, seed priming and their interactions on number of fruits per plant and fruit yield per plant in bell pepper

\begin{tabular}{|l|c|c|c|c|c|c|}
\hline \multicolumn{1}{|c}{$\begin{array}{c}\text { Plasma treatment } \\
\text { durations }\end{array}$} & \multicolumn{3}{|c|}{ Number of fruits per plant } & \multicolumn{3}{c|}{ Fruit yield per plant } \\
\cline { 2 - 9 } & Osmoprimed & $\begin{array}{c}\text { Non- } \\
\text { primed }\end{array}$ & $\begin{array}{c}\text { Mean } \\
\text { (Plasma) }\end{array}$ & Osmoprimed & $\begin{array}{c}\text { Non- } \\
\text { primed }\end{array}$ & $\begin{array}{c}\text { Mean } \\
\text { (Plasma) }\end{array}$ \\
\hline Vacuum & 13.00 & 12.33 & $\mathbf{1 2 . 6 7}$ & 0.71 & 0.66 & $\mathbf{0 . 6 9}$ \\
\hline $\mathbf{3}$ minutes & 16.00 & 15.67 & $\mathbf{1 5 . 8 3}$ & 0.93 & 0.90 & $\mathbf{0 . 9 2}$ \\
\hline $\mathbf{6}$ minutes & 17.00 & 16.67 & $\mathbf{1 6 . 8 3}$ & 1.00 & 0.97 & $\mathbf{0 . 9 9}$ \\
\hline $\mathbf{9}$ minutes & 15.33 & 14.67 & $\mathbf{1 5 . 0 0}$ & 0.88 & 0.83 & $\mathbf{0 . 8 6}$ \\
\hline $\mathbf{1 2}$ minutes & 14.67 & 14.00 & $\mathbf{1 4 . 3 3}$ & 0.82 & 0.78 & $\mathbf{0 . 8 1}$ \\
\hline $\mathbf{1 5}$ minutes & 14.00 & 13.33 & $\mathbf{1 3 . 6 7}$ & 0.77 & 0.73 & $\mathbf{0 . 7 5}$ \\
\hline Control & 11.67 & 11.00 & $\mathbf{1 1 . 3 3}$ & 0.62 & 0.58 & $\mathbf{0 . 6 0}$ \\
\hline Mean (Priming) & $\mathbf{1 4 . 5 3}$ & $\mathbf{1 3 . 9 5}$ & & $\mathbf{0 . 8 2}$ & $\mathbf{0 . 7 8}$ & \\
\hline
\end{tabular}

Table.3 Effect of plasma treatment, seed priming and their interactions on number of seeds per fruit and thousand seed weight in bell pepper

\begin{tabular}{|c|c|c|c|c|c|c|}
$\begin{array}{c}\text { Plasma } \\
\begin{array}{c}\text { Pleatment } \\
\text { durations }\end{array}\end{array}$ & \multicolumn{3}{|c|}{ Number of seeds per fruit } & \multicolumn{3}{c|}{ Thousand seed weight } \\
\cline { 2 - 7 } & $\begin{array}{c}\text { Osmopri } \\
\text { med }\end{array}$ & $\begin{array}{c}\text { Non- } \\
\text { primed }\end{array}$ & $\begin{array}{c}\text { Mean } \\
\text { (Plasma) }\end{array}$ & Osmoprimed & $\begin{array}{c}\text { Non- } \\
\text { primed }\end{array}$ & Mean (Plasma) \\
\hline Vacuum & 174.00 & 171.00 & $\mathbf{1 7 2 . 5 0}$ & 4.29 & 4.28 & $\mathbf{4 . 2 9}$ \\
\hline 3 minutes & 186.00 & 183.33 & $\mathbf{1 8 4 . 6 7}$ & 4.34 & 4.33 & $\mathbf{4 . 3 3}$ \\
\hline 6 minutes & 190.00 & 187.33 & $\mathbf{1 8 8 . 6 7}$ & 4.35 & 4.34 & $\mathbf{4 . 3 5}$ \\
\hline 9 minutes & 183.00 & 180.67 & $\mathbf{1 8 2 . 0 0}$ & 4.33 & 4.32 & $\mathbf{4 . 3 2}$ \\
\hline $\mathbf{1 2}$ minutes & 180.33 & 178.00 & $\mathbf{1 7 9 . 1 7}$ & 4.32 & 4.30 & $\mathbf{4 . 3 1}$ \\
\hline $\mathbf{1 5}$ minutes & 176.33 & 173.00 & $\mathbf{1 7 4 . 6 7}$ & 4.30 & 4.29 & $\mathbf{4 . 3 0}$ \\
\hline Control & 171.67 & 172.33 & $\mathbf{1 7 2 . 0 0}$ & 4.28 & 4.27 & $\mathbf{4 . 2 7}$ \\
\hline Mean (Priming) & $\mathbf{1 8 0 . 2 4}$ & $\mathbf{1 7 7 . 9 5}$ & & $\mathbf{4 . 3 2}$ & $\mathbf{4 . 3 0}$ & \\
\hline
\end{tabular}

\section{Number of seeds per fruit}

The number of seeds per fruit after harvesting as influenced by priming, plasma treatments and their interactions showed in Table 3. The present study revealed that maximum number of seeds per fruit (180.24) was recorded in osmopriming treatment, owing to the bigger and good quality fruits resulting in healthier and increased number of seeds, whereas minimum number of seeds per fruit (177.95) was recorded in non-primed seeds. Increase in number of seeds per fruit was significant in plasma treated seeds for 6 minutes duration (188.67), while minimum number of seeds per fruit was observed in control (172.00). A significant improvement in number of seeds per fruit was observed due to different exposure of plasma treatments. Seed exposed to plasma for 6 minutes recorded highest number of seeds per fruit (188.67). The seed kept under vacuum and not exposed to plasma showed significantly low number of seeds per fruit (172.50) compared to plasma treated seeds. The lowest number of seeds per fruit (172.00) was recorded in control where no treatments were given. Number of seeds per fruit is one of the important characters contributing to the seed yield. Zhou et al., (2011) observed increase in number of seeds per fruit in plasma treated tomato fruits and this increase may be due to increase in the 
photosynthetic activity, more number of fruits per plant and increase in fruit weight. The effect of plasma treatment in osmoprimed and non-primed seeds were constant and found to be non-significant for number of seeds per fruit.

\section{Thousand seed weight (gram)}

The data on thousand seed weight by the priming, plasma treatment and their interactions are presented in Table 3. Thousand seed weight differed significantly among the priming treatments. Maximum thousand seed weight was observed in osmoprimed seeds $(4.32 \mathrm{~g})$ whereas, the minimum was observed in non-primed seeds $(4.30 \mathrm{~g})$. Analysis of data revealed that exposure time of plasma to the seed significantly influenced the thousand seed weight. Higher thousand seed weight was, however, observed in the seed exposed to plasma for 6 minutes $(4.35 \mathrm{~g})$. The seed which was kept under vacuum and not exposed to plasma showed significantly lower thousand seed weight (4.29 g) compared to plasma treated seeds. The lowest thousand seed weight $(4.27 \mathrm{~g})$ was recorded in untreated control where no treatments were given. Thousand seed weight is an important parameter which decides the boldness of the seed. Higher thousand seed weight means bolder seeds and hence more will be the seed vigour which is one of the most important characters in seed studies. The studies revealed that priming treatment had a significant effect on thousand seed weight. This may be due to the bigger and good quality fruits resulting in bold seeds, which ultimately increase the seed weight (Jiang et al., 2014).

From the present study, it was observed that plasma treatment with 6 minutes duration can be used as an effective pre-sowing treatment to enhance the growth parameters, improve the fruit and seed quality. Reason may be removal of thin lipid layer due to exposure of seeds to plasma treatment, which makes the seed water repellant thereby improving the germination and seed quality (Sera et al., 2010). It also enhances the seed surface enrichment and inactivation of seed pathogens. It is a cost effective and ecologically sustainable method.

\section{Acknowledgements}

The authors thank FCIPT Institute for Plasma Research, Gandhinagar, Gujarat, India for the seed treatment and Dr YS Parmar, University of Horticulture and Forestry, Solan, Department of Seed Science and Technology for providing all the facilities to perform the study.

\section{References}

Agarwal A, Gupta S and Ahmed Z, Influence of plant densities on productivity of bell pepper (Capsicum annuum L.) under greenhouse in high altitude cold desert of Ladakh. Acta Horticulture, 2007, 756: 309-314.

Barlow EW and Haigh AM, Effects of seed priming on the emergence, growth and yield of tomatoes in the field. Acta Horticulture, 1987, 200: 153-164.

Dabrowska B, Suchorska K and Capecka E, Value of metrically conditioned seeds of hot pepper (Capsicum annuum L.) after one year of storage. Annales Universitatis Mariae Curie Sklodowska, 2002, 8: 369-375.

Dubinov AE, Lazarenko EM, Selemir VD, Effect of glow discharge air plasma on grain crops seed. IEEE Transactions on Plasma Science, 2000, 28(1): 180-183.

Filatova I, Azharonok V, Lushkevich V, Zhukovsky A, Gadzhieva G, Spasic K, Zivkovic S and Puac N, Plasma seeds treatment as a promising technique for 
seed germination improvement. International Conference on Phenomena in Ionized Gases. 2013, pp.14-19.

Harris D, Raghuwanshi BS, Gangwar JS, Singh SC, Joshi KD, Rashid A and Hollington P, Participatory evaluation by farmers of on-farm seed priming in Wheat in India, Nepal and Pakistan. Exp. Agriculture, 2001, 37: 403-415.

Jiang J, Xin H, Ling L, Jiangang L, Hanliang S, Qilai X, Renhong Y and Yuanhua D, Effect of cold plasma treatment on seed growth and germination of wheat. Plasma Science and Technology, 2014, 16(1): 54-57.

Krapivina SA, Alexander KF, Tatiana NL and Andrei B, Gas plasma treatment of plant seeds. United States Patent. 1994, pp. 54-56.

McDonald MB, Seed Deterioration: physiology, repair and assessment. Seed Science and Technology, 1999, 27: 177237.

Odell GB, Cantliffe DJ, Bryan $\mathrm{HH}$ and Stoffella PJ, Effect of priming on yield and quality. Horticulture Science, 1992, 27: 793-795.

Rashid A, Harris D, Hollington P A and Khattak RA, On-farm seed priming: a key technology for improving the livelihood of resource poor farmers on saline lands. Centre for Arid zone studies, University of Wales, UK, 2002.

Sadavarte KT and Gupta PK, Effect of seed treatment with plant growth regulators on germination, growth and yield of brinjal. The Punjab Horticulture Journal, 1963, 2: 195-199.

Sera B, Spatenka P, Sery M, Vrchotova N and Hruskova I, Influence of plasma treatment on wheat and oat germination and early growth. IEEE Plasma Science, 2010, 38(10): 2963-2967.

Sera B, Stranak V, Sery M, Tichy M and Spatenka P, Germination of Chenopodium album in response to microwave plasma treatment. Plasma Science and Technology, 2008, 10(4): 506-510.

Shah AR, Ara N and Shafi1G, Seed priming with phosphorus increased germination and yield of okra. African Journal of Agricultural Research, 2011, 6(16): 3859-3876.

Uche OJ, Adinde JO, Omije TE, Ager CJ and Anieke UJ, Influence of Hydropriming on germination and seedling emergence of green bell pepper (Capsicum annuum cv. Goliath). International Journal of Science and Nature, 2016, 7(1): 70-75.

Zhou Z, Huang Y, Yang S and Chen W, Introduction of a new atmospheric pressure plasma device and application on tomato seeds. Agricultural Sciences, 2011, 2(1): 23-27.

Zhou ZW, Huang YF, Yang S and Xiong D, Applicational effects of an atmospheric pressure plasma device. Progress in Electromagnetics Research Symposium Proceedings, 2012, 23(1): 1577-1580.

\section{How to cite this article:}

Cherry Nalwa, Ashok K. Thakur and Amit Vikram. 2018. Effect of Plasma Treatment on Growth Parameters and Seed Quality of Bell Pepper (Capsicum annuum L.) under Field Conditions. Int.J.Curr.Microbiol.App.Sci. 7(09): 745-751. doi: https://doi.org/10.20546/ijcmas.2018.709.089 